\title{
Studi Deskriptif Analitis Pemanfaatan Abu Serbuk Kayu Mahoni Sebagai Bahan Tambah Pembuatan Paving Block Untuk Mencari Kuat Tekan Optimum Berdasarkan SNI 03-0691-1989.
}

\author{
Ibnu Jauzi , Prihantono, Dadang Suyadi S.
}

\begin{abstract}
Paving block is concrete bricks for the floor is where many used as road pavement material on campus, office areas, sidewalks, roads, parking areas and so forth. This may imply that the use of paving block is so complex, so the need is also increasing because of convenience in installation and maintenance, so that specific treatment can be done to streamline its use in terms of quality. This study aimed to find out, what value of optimum compressive strength generated by the block paving using materials added mahogany ash powder with the addition of $0 \%, 5 \%$, $10 \%$ and $15 \%$ of the cement weight ratio.

This research was conducted at PUSLITBANG Bogor for burning sawdust, manufacturing plant specimen in Jati Makmur Court, Pondok Gede and compressive strength tests conducted at the Laboratory of Civil Engineering State University of Jakarta in May until November 2012.. This study tries to explain through experiments testing the compressive strength of paving block by using the added material is burned ash wood dust with a temperature of $6000 \mathrm{C}$ which is expected to generate an optimum compressive strength of the various variables that have been determined, the amount of $0 \%, 5 \%, 10 \%$ and $15 \%$ of the weight of cement. Later these materials can be used as an alternative material additive ingredient in the manufacture of concrete paving block in particular. In this study, using an experimental method, the population is paving block specimens with dimensions of length $10 \mathrm{~cm}$, width of $10 \mathrm{~cm}$ and $6 \mathrm{~cm}$ thick. The samples used were specimens paving block with a value of 0.35 FAS by 10 specimens with 4 groups namely A mix proportions; 10 pieces mixed specimen 1 Pc: 4 Ps plus sawdust ash mahogany $0 \%$ by weight of cement, B; mix 1 Pc: 4 Ps plus ash mahogany wood powder 5\% by weight of cement, C; mix 1 Pc: 4 Ps plus ash mahogany wood powder $10 \%$ of the weight of cement and D; mix 1 Pc: 4 Ps plus ash mahogany wood powder $15 \%$ weight of cement. Overall specimens aged 28 days planned in accordance with SNI-03-0691-1989 on compressive strength testing procedures for block paving. The data analysis technique used is the average test.

From these results, obtained average compressive strength of paving block by using a mixture of $1 \mathrm{Pc}$ : 4 Ps plus ash mahogany wood powder $10 \%$ is the best mix of $421 \mathrm{~kg} / \mathrm{cm} 2$ compressive strength, while the value of compressive strength mix 1 $P c$ : 4 Ps mahogany wood powder plus ash $0 \%$ is $243 \mathrm{~kg} / \mathrm{cm} 2$, compressive strength mix 1 Pc: 4 Ps plus mahogany sawdust ash amounted to $5 \%$ and the mixture $336 \mathrm{~kg} / \mathrm{cm} 2,1 \mathrm{Pc}: 4 \mathrm{Ps}$ plus ash mahogany wood powder $15 \%$ decrease results from the addition of $5 \%$ and $10 \%$ are being $254 \mathrm{~kg} / \mathrm{cm} 2$.
\end{abstract}

\section{Ibnu Jauzi}

Alumni Jurusan Teknik Sipil

Fakultas Teknik

Universitas Negeri Jakarta, 13220
Drs.Prihantono.,ST.,M.Eng

Staff Pengajar Jurusan Teknik Sipil Fakultas Teknik

Universitas Negeri Jakarta, 13220 email : prihantono2007@yahoo.co.id

\author{
Drs Dadang Suyadi S. MS \\ Staff Pengajar Jurusan Teknik Sipil \\ Fakultas Teknik \\ Universitas Negeri Jakarta, 13220
}




\section{PENDAHULUAN}

Dewasa ini perkembangan teknologi bahan bangunan berkembang sedemikian cepat. Perkembangan teknologi memungkinkan munculnya bahan bangunan yang dapat menggantikan bahan alam, sehingga memungkinkan banyak dimanfaatkan bahan-bahan lain. Demikian juga dalam bidang industri, teknologi berkembang dengan begitu cepat, hanya saja dalam prosesnya sering kali berpengaruh dari hasil buangan atau sisa-sisa hasil produksi (limbah) yang mempengaruhi lingkungan hidup itu dilupakan.

Laju pertumbuhan penduduk yang sangat tinggi juga berakibat pada tingginya kebutuhan akan sarana hunian. Pengembangan kawasan-kawasan hunian lebih lanjut akan memacu meningkatnya kebutuhan bahan bangunan. Bahan-bahan tersebut harus disediakan dalam jumlah besar dari alam maupun buatan. Salah satu cara untuk mengatasi permintaan kebutuhan bahan bangunan tersebut adalah dengan cara meningkatkan pemberdayaan sumber daya lokal yang berada di lingkungan kita. Pemberdayaan sumber daya lokal dapat berupa pemanfaatan sampah maupun limbah. Pemanfaatan sampah maupun limbah disamping dapat mengurangi pencemaran lingkungan juga dapat digunakan sebagai alternatif pengganti bahan bangunan yang sudah ada. Salah satu sampah atau limbah yang dapat dimanfaatkan dengan baik adalah limbah industri penggergajian kayu. Komponen limbah dari industri ini adalah kayu yang tersisa akibat proses penggergajian yang menurut bentuknya berupa serbuk gergaji, sedetan dan potongan-potongan kayu. Untuk menampung limbah tersebut pihak industri telah memberi tempat khusus di luar area, namun bila dibiarkan begitu saja secara terus menerus maka akan memenuhi area industri dan mengganggu proses produksi. Serbuk gergaji kayu merupakan bahan yang banyak tertimbun dan cenderung menjadi sampah karena pemanfaatannya yang masih sedikit / relatif kecil, sehingga perlu ditangani secara serius. Serbuk gergaji kayu juga merupakan salah satu jenis partikel kayu yang bobotnya sangat ringan dalam keadaan kering dan mudah diterbangkan oleh angin.

Hasil pembakaran limbah serbuk gergaji kayu akan menghasilkan briket arang dan arang aktif yang mengandung karbon yang juga diharapkan dapat meningkatkan dan 
memperbaiki sifat mekanik dan fisis beton yang jauh lebih baik dari beton yang tanpa bahan tambah tetapi tidak mengurangi mutu beton itu sendiri.

Dewasa ini serbuk gergaji kayu hanya dimanfaatkan untuk sebagian kecil kebutuhan saja. Misalnya sebagai bahan pembakaran batu bata. Ada beberapa penelitian tentang serbuk gergaji kayu yang pernah dilakukan di Ujung Pandang dan Medan. Penggunaanya masih terbatas pada campuran pembuatan bata cetak. Kemungkinan lain abu serbuk gergaji dapat digunakan sebagai bahan tambah pembuatan paving block. Melihat potensi serbuk gergaji kayu yang belum maksimal, maka perlu diusahakan untuk memanfaatkannya, khususnya sebagai bahan susun dalam pembuatan paving block.

Paving block merupakan bahan bangunan yang digunakan sebagai perkerasan permukaan jalan, baik jalan untuk keperluan pelataran, parkir kendaraan, jalan raya, ataupun untuk keperluan dekoratif pada pembuatan taman. Menurut SNI-03-0691-1989 pengertian paving block adalah :"Bata beton untuk lantai (paving block) adalah suatu komposisi bahan bangunan yang dibuat dari campuran semen portland atau bahan perekat hidraulis sejenis, air dan agregat dengan atau tanpa bahan tambahan lainnya yang tidak mengurangi mutu bata beton. Bahan tambah yang akan direncanakan untuk pembuatan paving block disini adalah abu dari serbuk kayu mahoni yang diharapkan dapat menambah kualitas dari pada paving block itu sendiri.

Dengan demikian, untuk mengetahui apakah abu serbuk kayu bisa digunakan sebagai bahan tambah pembuatan paving block, maka perlu adanya penelitian tentang pemanfaatan abu serbuk gergaji sebagai bahan tambah dalam pembuatan paving block dengan judul "Studi Deskriptif Analitis Pemanfaatan Abu Serbuk Gergaji Mahoni sebagai Bahan Tambah dalam Pembuatan Paving Block untuk Mencari Kuat Tekan Optimum Berdasarkan SNI 03-0691 1989"

Sesuai dengan perkembangan teknologi, beberapa peneliti terus memperbaiki sifat-sifat mortar antara lain menambah serat ke dalam adukan yang disebut mortar serat, yaitu mortar yang dibuat dari campuran semen dengan agregat halus dengan bahan tambahan 
serat. Jenis serat yang dapat digunakan untuk memperbaiki sifat kurang baik dari mortar adalah baja, plastik, kaca, karbon, dan serat alamiah.

Serbuk kayu gergaji merupakan salah satu jenis partikel kayu yang bobotnya sangat ringan dalam keadaan kering dan mudah diterbangkan oleh angin.

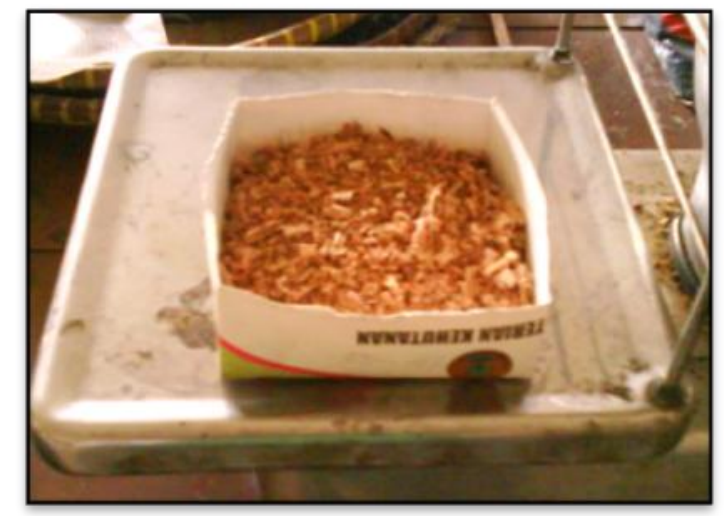

Gambar 1. Serbuk Gergaji Kayu Mahoni

Serbuk kayu itu sendiri dikenal sebagai limbah industri meubel yang banyak tertimbun dan cenderung menjadi sampah karena pemanfaatannya yang masih sedikit / relatif kecil, sehingga perlu ditangani secara serius. Selain itu, dewasa ini serbuk gergaji hanya dimanfaatkan untuk sebagian kecil kebutuhan saja. Misalnya sebagai bahan pembakaran batu bata.

Pemanfaatan serbuk kayu menjadi alternatif baru untuk memperoleh beton serat karbon yang diperoleh dari pembakaran limbah serbuk kayu. Hasil pembakaran limbah serbuk kayu akan menghasilkan briket arang dan arang aktif yang mengandung karbon yang juga diharapkan dapat meningkatkan dan memperbaiki sifat mekanik dan sifat fisis beton yang jauh lebih baik dari beton yang tanpa bahan tambah tetapi tidak mengurangi mutu (Yusnita, 2009).

Dalam hal ini untuk menghasilkan serbuk kayu menjadi karbon diperlukan pembakaran dengan oven khusus dengan suhu $600^{\circ} \mathrm{C}$ seperti proses dibawah ini : 


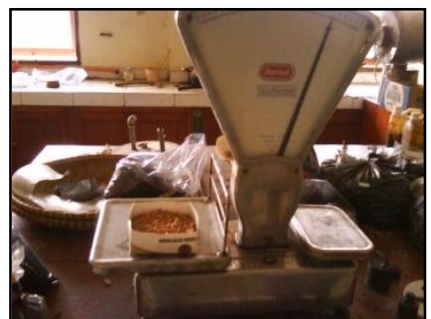

Serbuk Kayu Ditimbang

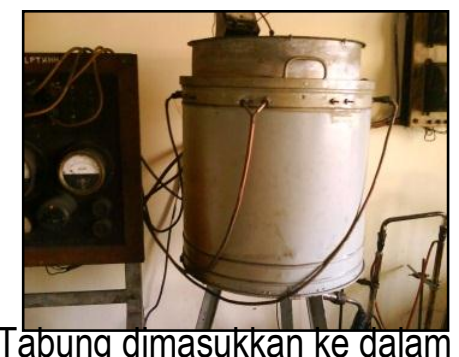

Oven Pembakaran

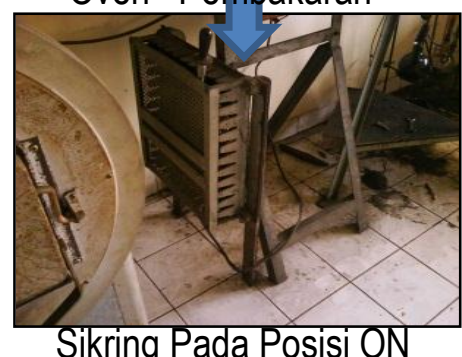

Sikring Pada Posisi ON
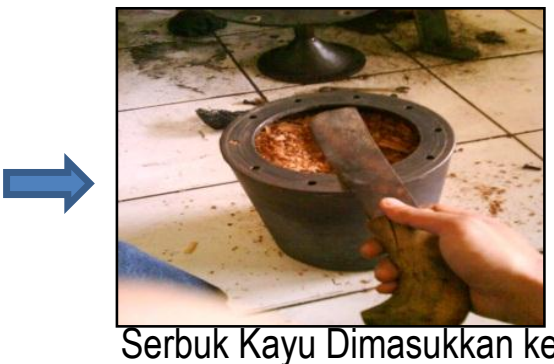
dalam Tabuna Pembakaran
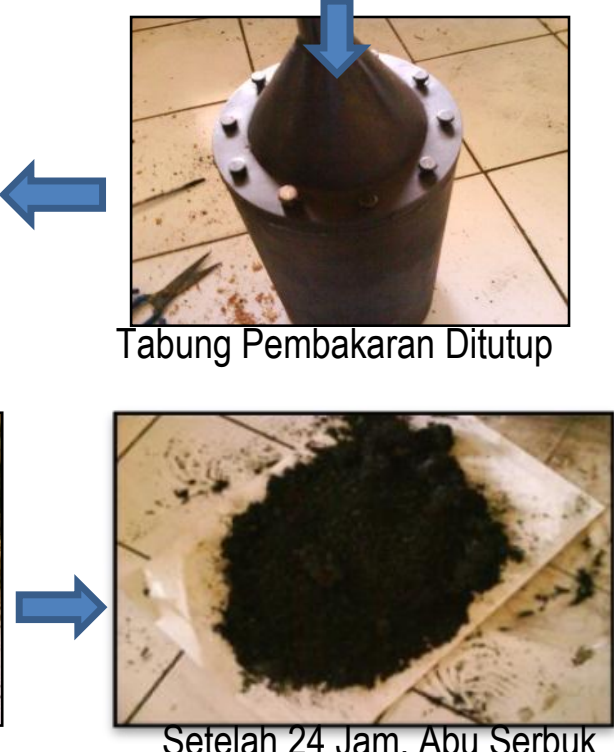

Kayu Dikeluarkaan

Gambar 2. Proses Pembakaran Abu Serbuk Kayu

Pada penelitian Sri Mulyati, Dahyunir Dahlan, Elvis Adril pada Laboratorium Material dan Struktur, Jurusan Fisika, FMIPA UNAND dengan judul "Pengaruh Persen Massa Hasil Pembakaran serbuk Kayu dan Ampas Tebu pada Mortar Terhadap Sifat Mekanik dan sifat Fisisnya", didapatkan hasil kuat tekan pada gambar 3 sebagai berikut :

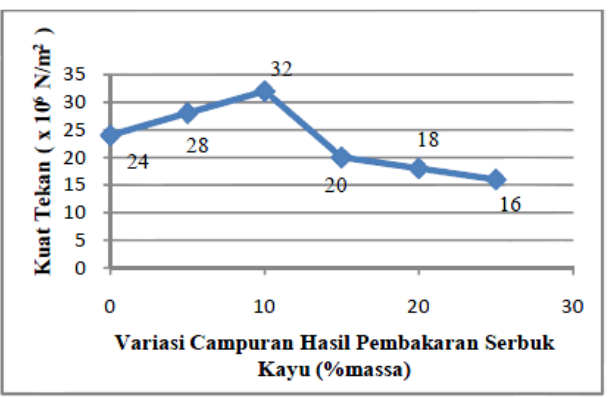

Gambar 3. Kuat Tekan terhadap Variasi Campuran Hasil Pembakaran Serbuk Kayu 
Pada diagram diatas menjelaskan bahwa penambahan pembakaran serbuk kayu pada mortar akan mempengaruhi kuat tekan pada benda uji.

Berdasarkan penelitian Kemino (1996:26), bata beton yang menggunakan subtitusi serbuk gergaji setelah dikonversikan sesuai mutu paving block dengan perbandingan $10 \%$ dari berat semen dihasilkan kuattekan rata-rata $286,431 \mathrm{~kg} / \mathrm{cm}^{2}$, perbandingan serbuk gergaji $20 \%$ dihasilkan kuat tekan rata-rata $254,277 \mathrm{~kg} / \mathrm{cm}^{2}$; perbandingan serbuk gergaji $30 \%$ dihasilkan kuat tekan rata-rata $217,404 \mathrm{~kg} / \mathrm{cm}^{2}$; dan pada perbandingan serbuk gergaji $50 \%$ dihasilkan kuat tekan rata-rata $165,091 \mathrm{~kg} / \mathrm{cm}^{2}$

Paving block adalah bata beton untuk lantai di mana banyak dimanfaatkan sebagai bahan perkerasan jalan di lingkungan kampus, areal perkantoran, trotoar, jalan raya, daerah perparkiran dan lain sebagainya. Hal ini dapat diartikan bahwa penggunaan paving block begitu kompleks, sehingga kebutuhannya juga meningkat karena kepraktisan dalam pemasangan dan pemeliharaanya. Berbagai usaha dilakukan dalam upaya peningkatan mutu dan kualitas akibat persaingan usaha poduksi dari paving block tersebut, salah satu usaha sebagai alternatif peningkatan mutu dan kualitas adalah dengan penambahan serbuk gergaji dalam pembuatan paving block. Limbah serbuk gergaji dari industri penggergajian kayu selama ini belum dimanfaatkan secara optimal hanya digunakan sebagai bahan pembakaran bata merah atau hanya ditumpuk di dekat areal penggergajian kayu.

Melihat potensi limbah serbuk gergaji yang sangat banyak perlu diadakan penelitian tentang pemanfaatan serbuk gergaji sebagai bahan tambah dalam pembuatan paving block.

Pada dasarnya abu serbuk gergaji mahoni hasil pembakaran limbah serbuk kayu akan menghasilkan briket arang dan arang aktif yang mengandung karbon yang juga diharapkan dapat meningkatkan dan memperbaiki sifat mekanik dan sifat fisis beton yang jauh lebih baik dari beton yang tanpa bahan tambah tetapi tidak mengurangi mutu. Namun 
apakah abu serbuk kayu mahoni tersebut dapat digunakan sebagai bahan tambah dalam pembuatan paving block masih perlu diuji lebih jauh.

Dalam pengujian ini yang ditekankan adalah kuat tekan dari paving block yang ditambah dengan abu serbuk kayu mahoni. Sehingga memungkinkan penggunaan paving block pada tempat yang menahan beban lebih besar sesuai standart yang telah ditentukan dalam SNI 03-0691-1989.

Ukuran benda uji pada saat pembuatan menggunakan ukuran panjang $21 \mathrm{~cm}$, lebar $10 \mathrm{~cm}$ dan tebal $6 \mathrm{~cm}$, namun dalam pengujian paving block dipotong terlebih dahulu menjadi panjang $10 \mathrm{~cm}$, lebar $10 \mathrm{~cm}$, dan tebal $6 \mathrm{~cm}$. Pelaksanaan pembuatan benda uji mengacu kepada tata cara dan perawatan beton yang berlaku untuk pengujian kuat tekan pada beton paving block.

Abu serbuk kayu mahoni ini nantinya akan menjadi bahan tambah dalam pembuatan paving block dengan perbandingan terhadap berat semen dengan proposi campuran masing-masing $0 \%, 5 \%, 10 \%$ dan $15 \%$. Diharapkan nantinya pada campuran abu serbuk kayu mahoni tersebut akan menghasilkan kuat tekan yang optimum melebihi standar yang ditentukan dalam SNI 03-0691-1989.

\section{METODA}

Metoda penelitian yang digunakan dalam penelitian ini adalah metode eksperimen di laboratorium dengan benda uji paving block yang menggunakan serbuk gergaji yang dibakar sebagai bahan tambah dengan perbandingan dari berat semen.

Dalam penelitian ini sebelum dilakukan pengujian hipotesis, terlebih dahulu data perlu diuji normalitas dan homogenitas. Dalam hal uji normalitas yang digunakan uji liliefors. Untuk uji homogenitas yang digunakan uji bartlett. Untuk pengujian hipotesis pertama pengujian analisis non parametrik dengan menggunakan uji tanda. 
Alur Penilitian

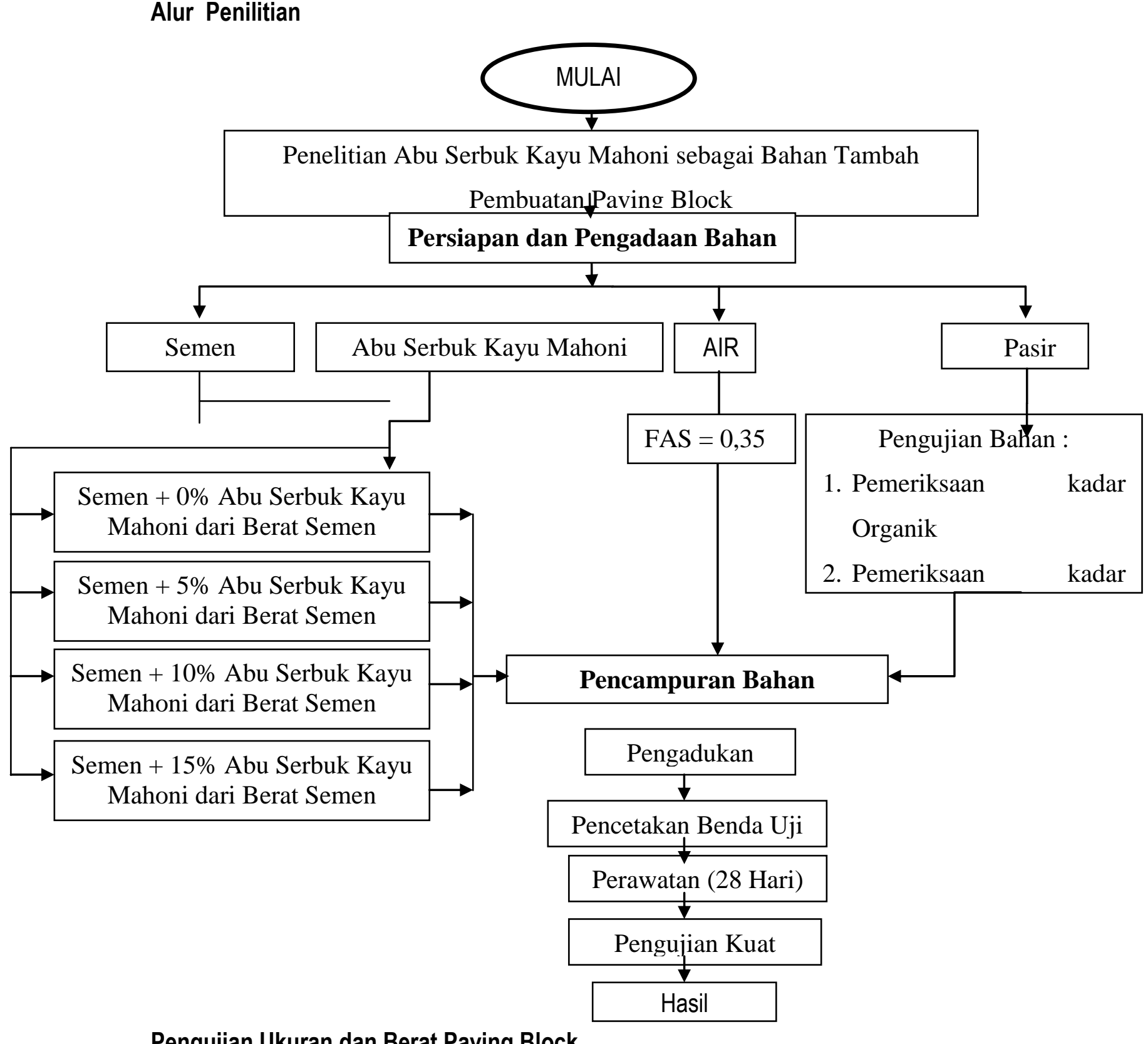

Pengujian Ukuran dan Berat Paving Block
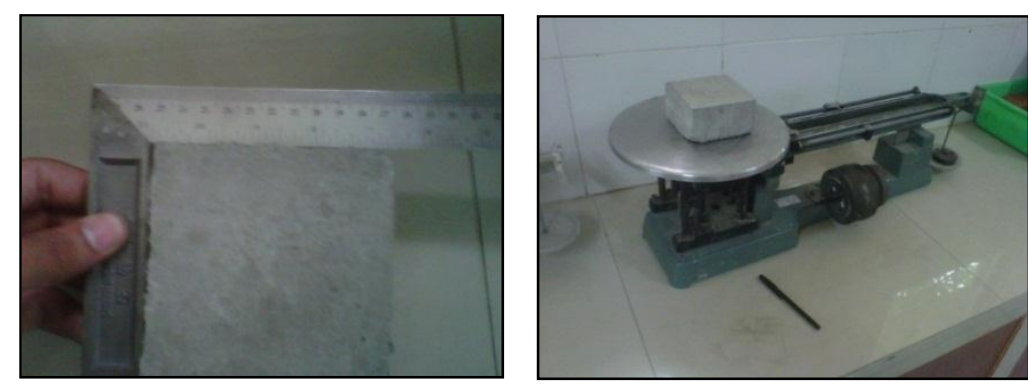

Pengujian Ukuran (kiri) dan Berat Paving Block (kanan) 


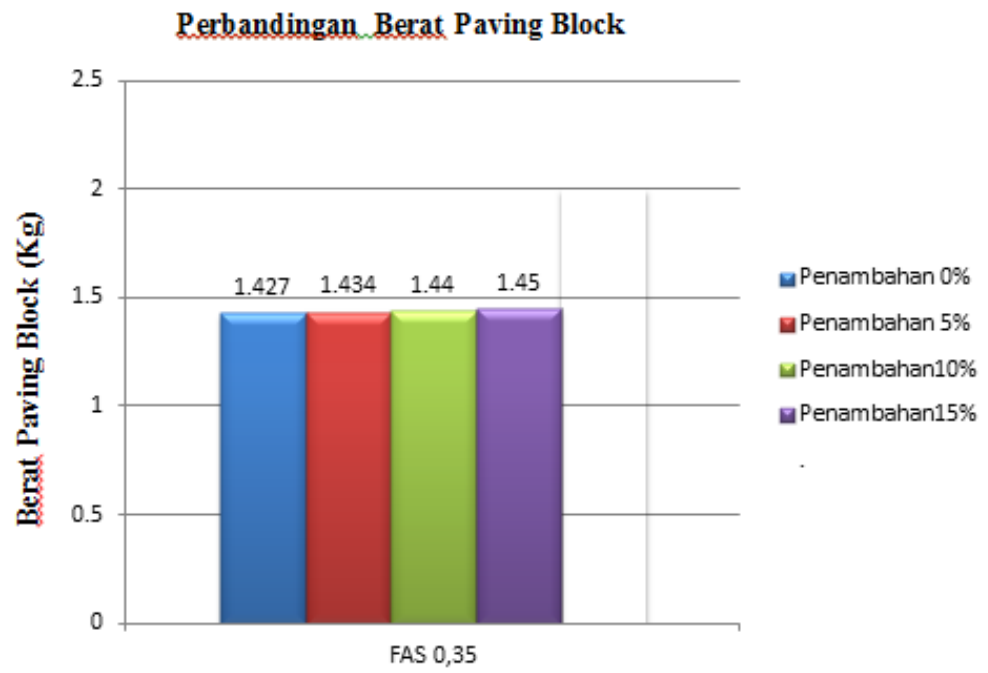

Diagram Perbandingan Berat Paving block

Dari gambar diagram di atas dapat dilihat bahwa masing-masing campuran pada paving block dengan proporsi penambahan abu serbuk kayu mahoni sebesar $0 \%, 5 \%, 10 \%$ dan $15 \%$ memiliki berat yang hampir sama tersebut bahwa berat per volume untuk masingmasing campuran hampir sama yaitu berkisar $\pm 1.4 \mathrm{~kg}$. Apabila dilihat berdasarkan hasil tabel diatas bahwa semakin banyak penambahan abu serbuk kayu mahoni maka berat dari pada paving block semakin bertambah. Hal ini menunjukkan adanya pengaruh abu serbuk kayu mahoni sebagai bahan tambah terhadap berat semen dapat menambah beban daripada paving block yang dihasilkan.

\section{Pengujian Kuat Tekan Paving Block}

Data-data hasil pengujian untuk tiap perlakuan dari jarum penunjuk mesin kuat tekan dapat dilihat pada tabel dan gambar berikut ini.

Tabel 1. Hasil Pengujian Rata-rata Kuat Tekan Paving Block

\begin{tabular}{|c|c|}
\hline Kelompok & Nilai rata-rata kuat tekan $\left(\mathbf{k g} / \mathrm{cm}^{2}\right)$ \\
\hline I & 243 \\
\hline II & 366 \\
\hline III & 421 \\
\hline IV & 254 \\
\hline
\end{tabular}




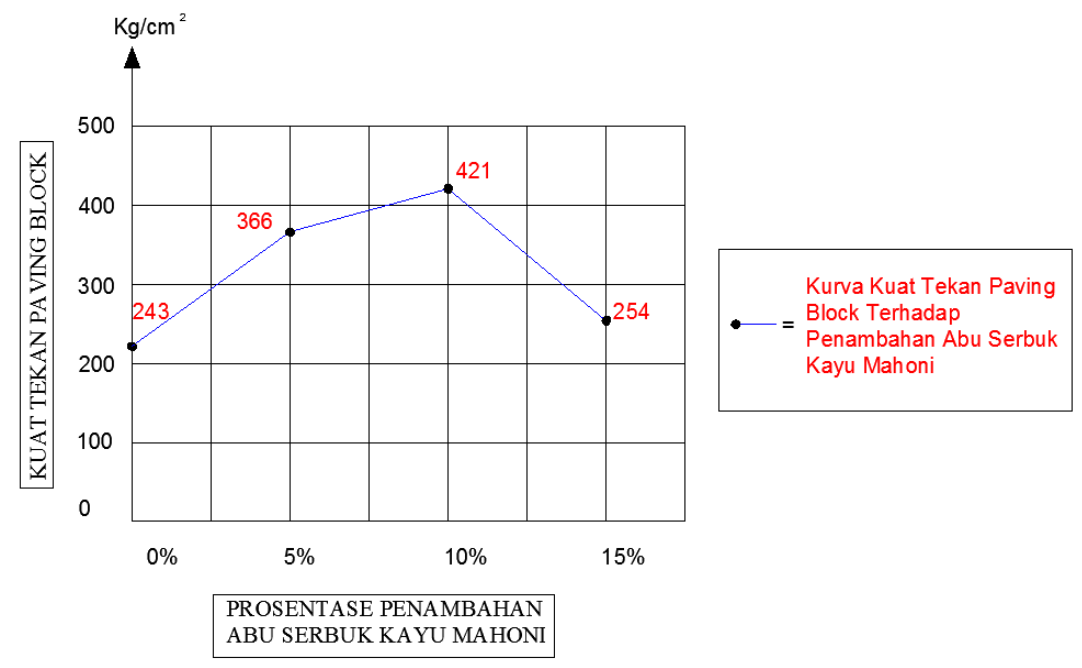

Grafik Hasil Rata-rata Pengujian Kuat Tekan Paving Block

Berdasarkan tabel dan gambar pada halaman kuat tekan paving block bertambah seiring dengan penambahan hasil pembakaran serbuk kayu pada campuran paving block. Namun, peningkatan ini hanya sampai titik tertentu, dimana penambahan lebih lanjut jumlah abu serbuk kayu mahoni justru menurunkan kuat tekan paving block. Titik tertinggi dalam eksperimen yaitu pada paving block yang menggunakan proporsi penambahan abu serbuk kayu mahoni sebesar 10\% dari berat semen. Dan titik terendah di dalam eksperimen sebesar yaitu pada paving block yang menggunakan proporsi penambahan abu serbuk kayu mahoni sebesar $0 \%$ dari berat semen.

Dengan demikian hasil pembakaran serbuk kayu dengan variasi campuran 10\% massa merupakan variasi campuran optimum. Jika digunakan abu serbuk kayu mahoni melebihi variasi campuran tersebut maka akan menurunkan kekuatan paving block.

Fenomena ini dapat dijelaskan sebagai berikut. Tanpa hasil pembakaran serbuk kayu, pada campuran paving block terdapat ruang kosong (porositas). Gaya ikat yang terbentuk hanya gaya ikat antar pasir dan semen. Dengan menambahkan sedikit hasil pembakaran serbuk kayu, partikel-partikel hasil pembakaran serbuk kayu mulai mengisi ruang kosong pada campuran paving block. Akibatnya muncul ikatan baru yang bekerja pada, yaitu ikatan antara campuran pasir dengan semen dan ikatan antara campuran pasir dengan semen dan partikel hasil pembakaran serbuk kayu. Jika hasil pembakaran serbuk kayu 
ditambah lebih lanjut maka makin banyak terbentuk ikatan antara campuran pasir dengan semen dan partikel hasil pembakaran serbuk kayu sehingga kekuatan mortar makin meningkat.

Jika hasil pembakaran serbuk kayu diperbanyak lagi maka mulai muncul ikatan antar hasil pembakaran serbuk kayu itu sendiri. Karena hasil pembakaran serbuk kayu mengandung banyak karbon di mana karbon merupakan grafit maka ikatan antar karbon cukup lemah, bahkan lebih lemah dari ikatan antar karbon dan mortar.

Dengan demikian kehadiran ikatan antara karbon akan memperlemah kekuatan mortar. Penambahan karbon makin banyak menyebabkan jumlah ikatan antar karbon makin banyak sehingga mortar makin rapuh. (Abdullah, 2008).

\section{Analisis keretakan pada paving block}

Analisa lebih lanjut terhadap paving block dapat diperlihatkan pada kondisi tipikal keruntuhan atau keretakan beton akibat pengaruh penambahan abu serbuk kayu mahoni. Untuk menganalisa pola retak beton terdapat jenis pola retak beton yang sudah tertera pada gambar berikut.

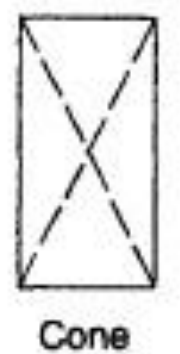

(a)

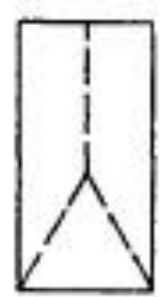

Cone and

Split (b)

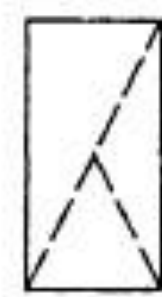

Cone and Shear (c)

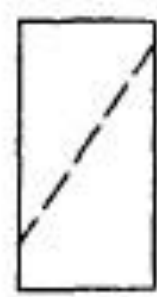

Shear

(d)

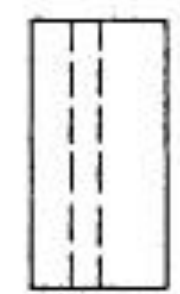

(ө)

Fig. 1: Sketches of types of fracture

SumberASTM C 39-03

Gambar Pola Retak Beton 


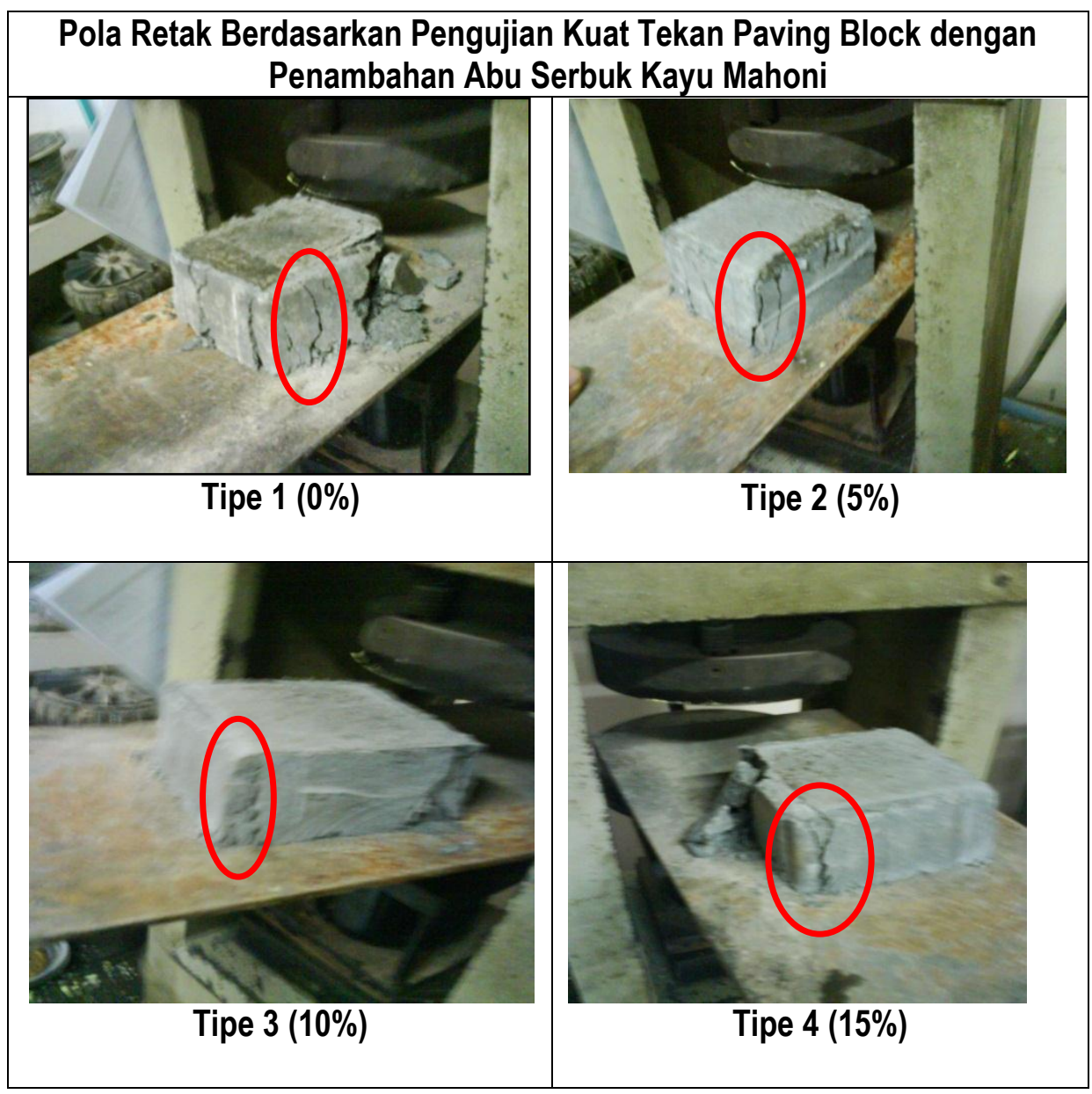

Pola Retak pada Paving Block

Pola retak paving block terhadap penambahan abu serbuk kayu mahoni dapat dilihat bahwa baik komposisi penambahan $0 \%, 5 \%, 10 \%$ dan $15 \%$ pada umumnya memiliki pola retak cone and split failure. Hal ini dapat dilihat dari retak pertama yang terbentuk dari sisi atas paving block, kemudian membentuk garis dengan arah bercabang dan retakan memusat pada tengah paving block.

Namun dapat dilihat pada gambar tersebut dimana retakan yang terjadi juga akibat geser. Hal ini menunjukkan bahwa nilai kuat tekan yang didapat telah terpengaruhi oleh nilai kuat geser dari beton tersebut, sehingga terdapat kemungkinan bahwa kegagalan yang terjadi bukan murni akibat tekan, namun ada juga karena geser. 
Failure karena geser ini terjadi karena ketika pengujian, paving block tidak benar-benar tertahan pada sisi atas dan sisi bawahnya, namun terdapat sisi yang dapat bergeser, dalam hal ini adalah sisi bawah yang tidak diberi caping, sehingga ketika pembebanan berlangsung, beban dari atas maupun dari bawah paving block tidak bertemu dan justru beban menjadi terpusat pada satu sisi. Hal inilah yang dapat mengurangi nilai kuat tekan beton sebenarnya.

\section{KESIMPULAN}

Kesimpulan yang dapat ditarik dari hipotesis yang telah di uji adalah sebagai berikut :

1. Pada taraf signifikansi $(\alpha)=0,01$ data kuat tekan paving block yang dihasilkan yang menggunakan abu serbuk kayu mahoni sebagai bahan tambah dari perbandingan berat semen dengan tingkat prosentase $0 \%, 5 \%, 10 \%$ dan $15 \%$ semua terdistribusi normal

2. Nilai optimum kuat tekan paving block dengan prosentase $10 \%$ abu serbuk kayu menghasilkan kuat tekan rata-rata $421 \mathrm{~kg} / \mathrm{cm}^{2}$ lebih besar dari persyaratan nilai kuat tekan standar SNI 03-0691-1989 yaitu sebesar $200 \mathrm{~kg} / \mathrm{cm}^{2}$

3. Nilai kuat tekan rata-rata paving block yang tidak menggunakan abu serbuk kayu sebagai bahan tambah pembuatan paving block adalah $243 \mathrm{~kg} / \mathrm{cm}^{2}$, sedangkan yang menggunakan bahan tambah abu serbuk kayu mahoni $5 \%$ adalah $366 \mathrm{~kg} / \mathrm{cm}^{2}$, pada penambahan $10 \%$ adalah sebesar $421 \mathrm{~kg} / \mathrm{cm}^{2}$ dan pada penambahan $15 \%$ adalah sebesar $254 \mathrm{~kg} / \mathrm{cm}^{2}$, dari ke empat nilai rata-rata tersebut memenuhi syarat mutu paving block karena lebih besar dibandingkan dengan kuat tekan yang terdapat pada SNI 03-0691-1989 dengan nilai kuat tekan terendah rata-rata sebesar $200 \mathrm{~kg} / \mathrm{cm}^{2}$.

4. Campuran yang paling optimum adalah yang menggunakan penambahan abu serbuk kayu mahoni sebesar $10 \%$ yang menghasilkan kuat tekan rata-rata $421 \mathrm{~kg} / \mathrm{cm}^{2}$

5. Berdasarkan SNI 03-0691-1989 pada pengujian hasil kuat tekan paving block, penambahan abu serbuk kayu dengan penambahan 0\% dan 15\% dengan kuat ratarata $243 \mathrm{~kg} / \mathrm{cm}^{2}$ dan $246 \mathrm{~kg} / \mathrm{cm}^{2}$ terdapat pada mutu III, penambahan abu serbuk kayu dengan penambahan $5 \%$ dengan kuat rata-rata $366 \mathrm{~kg} / \mathrm{cm}^{2}$ terdapat pada mutu II, penambahan abu serbuk kayu dengan penambahan 10\% dengan kuat rata-rata 421 $\mathrm{kg} / \mathrm{cm}^{2}$ terdapat pada mutu I. 
6. Pemanfaatan penambahan abu serbuk kayu mahoni yang berfungsi sebagai bahan tambah dari berat semen didalam pembuatan paving block memerlukan kecermatan dan ketepatan terutama mengenai prosentasi dan proses pengadukan agar diperoleh nilai kuat tekan yang lebih tinggi dari nilai kuat tekan standar menurut SNI 03-06911989

\section{DAFTAR PUSTAKA}

Andrias, dkk. 1996. Pengembangan Teknologi Pengolahan Serbuk Gergaji sebagai Bahan Pengisi pada Pembuatan Bata Cetak. Balai Industri Ujung Pandang

Andriati.1996. Penelitian Pemanfaatan Semen Abu Terbang untuk Pembuatan Paving Block. Jurnal Penelitian Permukiman I. Vol XII.No 1-2.Arianto, A. 2005.

Kemino.1996. Penelitian Limbah Industri Pengolahan Kayu sebagai Bahan Pembuatan Bata Bangunan Cetak . Jurnal Penelitian Permukiman I.Vol XII. No1-2.

Nadhiroh, Masruri. 1992 Penelitian Pemanfaatan Limbah Industri Timah untuk Bahan Jurnal Penelitian Permukiman I.Vol VII : 43-51

Ningrum, Merry Siti. 2003. Studi Kuat Tekan Paving Block dengan Substiusi Abu Insenator. Universitas Negeri Jakarta

Satya, M. 2002. Pengaruh Subtitusi Abu Sekam Padi Terhadap Kuat Tekan Paving Block. Skripsi. Semarang : Universitas Negeri Semarang.

Septiandini, Erna. 2007. Rencana Program Kegiatan Pembelajaran Semester (RPKPS) dan Bahan Ajar Mata Kuliah Praktek Uji Bahan, Prodi S1 Teknik Sipil, Fakultas Teknik, Universitas Negeri Jakarta. Jakarta : Teknik Sipil Universitas Negeri Jakarta.

Tjokrodimuldjo. K, 1996, Teknologi Beton,Nafigiri, Yogyakarta.

Yusnita, 2009, Pengaruh Konsentrasi Abu Serbuk Kayu Terhadap Kuat Tekan dan Sifat Fisis Beton, Skripsi, Universitas Sumatera Utara, Medan. 